\title{
A EDUCAÇÃO NOS MARCOS DAS TRANSFORMAÇÕES DO RURAL CONTEMPORÂNEO
}

\author{
Arilson Favareto*
}

\begin{abstract}
RESUMO: A Humanidade vive um momento de transição de paradigmas nas formas de relação entre os espaços urbanos e rurais. O caso brasileiro não é diferente. O paradigma agrário, que sustentou as principais teorias e políticas destinadas às áreas rurais no século passado vem gradativamente dando lugar a uma nova visão, na qual a exportação de bens primários para as áreas urbanas passa a ser apenas uma, dentre as várias funçôes desempenhadas por aqueles espaços. Este movimento histórico precisa ser acompanhado por uma atualização do perfil das políticas públicas, em geral, e pelas políticas educacionais, em particular, ao novo contexto. $\mathrm{O}$ artigo apresenta as principais tendências em curso nesta transição de paradigmas e algumas de suas consequências para uma nova geração de políticas.
\end{abstract}

Palavras-chave: Desenvolvimento rural. Paradigma agrário. Nova ruralidade. Educação rural.

\section{EDUCATION IN THE MILESTONE OF TRANSFORMATIONS IN THE CONTEMPORARY RURAL CONTEXT}

\begin{abstract}
Humanity is experiencing a period of transition of paradigms regarding the rural-urban space relations. The Brazilian case is no different. The agrarian paradigm that underlay the main theories and policies destined to rural areas in the last century is gradually giving way to a new vision in which the export of primary goods to urban areas is now only one, among the various functions performed by those spaces. This historical movement must be accompanied by an update of the profile of public policies, in general, and of the educational policies in particular, adjusted to the new context. The article presents the main trends under way in this transition of paradigms and some of their consequences for a new generation of policies.
\end{abstract}

Keywords: Rural development. Agrarian paradigm. New rurality. Rural education.

\footnotetext{
* Universidade Federal do ABC (UFABC), Núcleo de Estudos Estratégicos sobre Democracia, Desenvolvimento e Sustentabilidade. Pesquisador colaborador do Centro Brasileiro de Análise e Planejamento (Cebrap). E-mail de contato: arilson.favareto@ufabc.edu.br.
} 


\title{
ÉDUCATION DANS LE CADRE DES TRANSFORMATIONS DU RURAL CONTEMPORAIN
}

\begin{abstract}
RESUMÉ: L'Humanité connaît une période de transition de paradigmes dans les formes de relation entre les zones urbaines et rurales. Le cas du Brésil n'est pas différent. Le paradigme agraire qui a soutenu les principales théories et politiques pour les zones rurales au siècle dernier cède progressivement la place à un nouveau regard sous lequel l'exportation de produits primaires vers les zones urbaines devient une fonction parmi celles exercées par ces espaces. Ce mouvement historique doit être accompagné d'une mise à jour du profil des politiques publiques en général et des politiques de l'éducation en particulier, cela au nouveau contexte. L'article présente les principales tendances en cours dans cette transition de paradigmes et certaines de ses conséquences pour une nouvelle génération de politiques.
\end{abstract}

Mots-clés: Développement rural. Paradigme agraire. Mouvelle ruralité. Éducation rurale.

\section{Introdução}

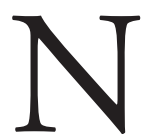

ma das principais caraterísticas das regióes rurais brasileiras neste início do século XXI é que nem todos os que ali vivem são ou serão agricultores. Esta mudança é decisiva para se pensar o ambiente educacional e as políticas públicas, de maneira a contribuir para que esta população possa participar da vida da comunidade e fortalecer o tecido social local. A exposição parte destas transformaçóes demográficas e econômicas do Brasil interiorano para, a partir disso, analisar criticamente as políticas públicas, destacadamente as concepçóes e projetos para a educaçáo em áreas rurais.

A ideia central que se pretende demonstrar pode ser adiantada desde já. As últimas décadas do século passado foram palco de transformaçóes qualitativas na essência da ruralidade. São mudanças que atingem as três dimensóes fundamentais que permitem definir o rural: as relaçóes de proximidade entre as pessoas que ali vivem, as formas de uso social dos recursos naturais, e as interdependências entre os campos e as cidades. As mudanças ocorridas nestas três dimensóes levaram a nada menos do que uma erosão das bases daquilo que se poderia chamar de paradigma agrário e que sustentou as visóes científicas e normativas sobre o mundo rural ao longo de todo o Século XX. Em seu lugar, os tempos atuais representam um momento de transição entre a velha ruralidade - na qual o futuro destes espaços dependia fundamentalmente da promoção das atividades primárias realizadas no seu interior e das maneiras de fazê-lo - e uma nova ruralidade - cujo conteúdo exige a superação de dicotomias que não mais se sustentam, como a oposição estanque entre o rural e o urbano, os campos e as cidades. 
Com a emergência destes novos processos sociais e econômicos, vivemos um momento de transição nos quadros cognitivos para interpretá-los. Não se trata ainda da emergência de um novo paradigma, naquele sentido dado por Thomas Kuhn, de uma nova visão partilhada sobre o que é o rural. Diferente disso, coexistem hoje duas visôes, em certa medida antagônicas sobre o que é o rural e sobre como promover o desenvolvimento destes espaços. No campo das instituiçóes e políticas, isso se materializa sob a forma de um discurso inovador, mas também na permanência de instrumentos e prioridades ainda condizentes com o estatuto da velha ruralidade. Daí a importância em analisar as tendências em curso no rural brasileiro, os problemas de definiçáo contidos nestas tendências, e quais as implicaçóes deste novo momento para pensar as políticas públicas, inclusive as políticas educacionais.

\section{As transformações do mundo rural contemporâneo ${ }^{1}$}

Tendem a soar como bizantinas as discussôes e polêmicas que, às vezes, se travam em torno das diferentes maneiras de definir unidades espaciais ou a esfera de atuação de programas e políticas públicas. Mas as próximas páginas pretendem mostrar que se trata justamente do contrário: sem atentar para o que está por trás de cada definição e sem um exercício permanente de atualização destas categorias de definição, não há como captar a verdadeira configuração destas unidades do mundo real, nem tampouco se pode identificar tendências em curso. Sem isso, para usar um conceito de Amable \& Palombarini (2003), políticas e investimentos públicos perdem aderência ao objeto de intervenção e, por aí, veem sua eficácia ser fortemente restringida. Esta afirmação de caráter geral é, particularmente, válida quando se trata de pensar quais as implicaçóes das diferentes formas de definir o que é o rural brasileiro para efeitos de desenho e implementação de políticas públicas. Responder a esta questão é o principal objetivo desta primeira seção.

As ideias de rural ou de urbano são similares a tantas outras que só existem em relação direta com seu par oposto, tal como acontece com o masculino e o feminino, com o sagrado e o profano, com a pobreza e a riqueza. Para pensar os termos da relação entre os dois polos, a primeira dificuldade que se impóe é justamente sua própria delimitação.

$\mathrm{Na}$ economia rural, a tradiçáo sempre foi pensar seu objeto como algo relacionado à produção primária, incluindo assim, além da agricultura, a exploração florestal e outras atividades extrativas, mas tendo sempre por universo as famílias ou empresas ligadas a este setor. É evidente que isto teve, durante determinado período, uma base histórica, uma correspondência no real que lhe sustentava, mesmo que como visão distorcida ou parcial: o peso determinante da agropecuária e do extrativismo na vida rural. Porém, como se sabe, com o passar 
do tempo os termos de troca foram se alterando e a participação da agropecuária apresentou tendência declinante sob o ângulo da formação da renda das famílias rurais. Da mesma forma, o desenvolvimento tecnológico e o correspondente descarte de trabalho com a tecnificação e a mecanização tornaram igualmente declinante a participação do setor primário na alocação de trabalho.

Na sociologia, a própria criação do ramo dedicado ao rural veio apoiada na oposiçấo comunidade-sociedade, restringindo seu objeto ao estudo das várias dimensôes da vida social dos pequenos lugarejos, também com forte presença da agricultura na determinação dos rumos dos indivíduos ou das economias locais, e sempre pensando esta esfera com uma relativa autonomia e em aberto contraste com a sociedade envolvente. A clássica definição de Sorokin elenca os seguintes traços marcantes: as diferenças ocupacionais entre os dois espaços, com maior peso das atividades primárias no caso dos espaços rurais; as diferenças ambientais, com maior dependência da natureza no rural; o tamanho da população; a densidade demográfica; o grau de diferenciação social e de complexidade; as características mais restritas de mobilidade social no rural; e as diferenças de sentido da migração, sempre do campo para a cidade, onde estariam as melhores oportunidades. Também aqui os processos históricos trataram de solapar parte das características tradicionalmente associadas ao rural. São traços que claramente falam mais da condição rural nos anos 1930 do século XX, quando tal definição foi formulada, do que exatamente de caracteres fundamentais da ruralidade contemporânea. É preciso, portanto, separar caracteres estruturais de definição do que é rural e do que é urbano das distintas funçôes que estes espaços cumpriram ao largo do tempo.

De acordo com Abramovay (2003), três são as dimensóes definidoras fundamentais da ruralidade: a proximidade com a natureza, a ligação com as cidades, e as relaçóes interpessoais derivadas da baixa densidade populacional e do tamanho reduzido de suas populaçóes. O que muda na nova etapa é o conteúdo social e a qualidade da articulação entre estas instâncias.

No que diz respeito à proximidade com a natureza, os recursos naturais, antes voltados para a produção de bens primários, são agora crescentemente objeto de novas formas de uso social, com destaque para a conservação da biodiversidade, o aproveitamento do potencial paisagístico disto derivado, e a busca de fontes renováveis de energia. Quanto à relação com as cidades, os espaços rurais têm deixado de ser meros exportadores de bens primários para dar lugar a uma maior diversificação e integração intersetorial de suas economias, com isso arrefecendo, e em alguns casos mesmo invertendo, o sentido demográfico e de transferência de rendas que vigorava no momento anterior. As relaçōes interpessoais, por fim, deixam de apoiar-se numa relativa homogeneidade e isolamento. Elas passam a se estruturar a partir de uma crescente individuação e heterogeneização. Um movimento compatível com a maior mobilidade física, com o novo perfil populacional, e com a crescente integraçáo entre mercados que antes eram mais claramente 
autônomos no rural e no urbano - mercados de bens e serviços, mas também o mercado de trabalho e o mercado de bens simbólicos (FAVARETO, 2007). Essa mudança qualitativa pode ser melhor compreendida mediante rápida exposição, tendo por base exemplos da experiência internacional.

Um dos principais livros sobre o desenvolvimento rural no mundo contemporâneo é justamente consagrado à análise da realidade dos EUA - Rural Development in the United States, de Galston \& Baehler (1995). Nele, os autores destacam como, ao longo da história americana, foram mudando as vantagens comparativas das áreas rurais. Numa primeira longa etapa da formação do território americano, a grande vantagem comparativa estava situada na disponibilidade de produtos primários: madeira, carvão, minerais, produtos agrícolas. A busca por estes recursos orientou a ocupação do espaço e foi, por bom tempo, a principal fonte de trabalho e riqueza.

Obviamente, com o passar do tempo a importância desta produção foi decrescendo, tanto em termos de pessoal ocupado como de riqueza gerada. As inovaçóes tecnológicas e a consolidação de cidades deram lugar a uma diversificação da base produtiva, com o desenvolvimento crescente de atividades de transformaçáo e serviços. Nesta etapa, os espaços rurais passam a ter, como fatores de atração de indústrias e investimentos, seus terrenos e mão de obra mais baratos, e aspectos como menor fiscalização e sindicalização. A principal vantagem passa a ser a localização, já que o aproveitamento desses fatores, menos onerosos, nas áreas rurais só eram viáveis em razão de certa distância dos centros mais dinâmicos, compensando custos de transporte. Mas, da mesma maneira que o avanço tecnológico permite uma diminuição de custos de produção e a introdução de técnicas poupadoras de mão de obra na agricultura, na atividade manufatureira acontece o mesmo. Com isso, o dinamismo passa a se concentrar no setor terciário. Nas duas últimas décadas do século passado, foram os condados que mais oferecem serviços ligados ao aproveitamento de amenidades rurais - paisagens naturais ou cultivadas, ar puro, água limpa, atrativos culturais - aqueles que apresentaram maior crescimento. Constituem exceção lugares que contaram com tipos muito especiais de investimentos como cassinos, prisôes ou centrais de distribuição dos correios. Mas trata-se de investimentos que, por motivos óbvios, não podem ou devem ser a base de uma estratégia a ser preconizada para as áreas rurais.

No caso da Itália, apresentado em Veiga (2006), é evidente o contraste entre áreas rurais que dependem essencialmente das rendas obtidas através da exportação de bens primários, eventualmente industrializados, e outras onde a economia está assentada nos deslocamentos de rendas geradas e obtidas nas cidades. Uma divisão que encontra certa correspondência em características naturais, como o relevo. Planícies e planaltos, no primeiro caso, proximidade de colinas e montanhas, no segundo. Esta divisáo parece ter sido influenciada diretamente pela evoluçáo de todo um leque de fenômenos relacionados ao turismo, por sua 
vez estreitamente determinado pelo aumento do tempo livre e da renda, e, por consequência, também do aumento das atividades de lazer de crescentes estratos e camadas sociais. Além da conservação do patrimônio natural, que está na raiz deste tipo de fenômeno, e da exploração econômica das decorrentes amenidades, cuja maior expressáo é a atividade turística, o mesmo estudo mostra também que há um terceiro vetor de valorização da ruralidade: a exploração de novas fontes de energia.

Claro que a agricultura de commodities continua tendo um peso enorme na conformação dos espaços rurais e, igualmente, que atividades terciárias sempre existiram neste meio. O que destacam Galston \& Baehler (1995) e Veiga (2006) é a ênfase crescente neste segundo conjunto, tanto em termos de pessoas ocupadas, como de riqueza gerada, mas, principalmente, pelo que ele traz de novo para as instituições voltadas ao desenvolvimento rural: a importância crescente da natureza e dos valores não diretamente monetizáveis.

Neste quadro de mudança de vantagens comparativas, uma constatação incontornável, já destacada aqui para o caso italiano, é que nem todas as localidades rurais têm as mesmas condiçóes de experimentar um processo de desenvolvimento baseado na exploração de suas amenidades. A baixa densidade populacional, característica básica destes espaços, é um complicador para a diversificação econômica. O perfil demográfico e as características do tecido social, marcadamente das áreas rurais estagnadas ou daquelas que perdem população é outro: há uma fragilidade dos laços sociais externos, carência de oportunidades locais, baixa expectativa quanto às possibilidades de mobilidade social e de ampliaçấo das interaçóes. Distância de centros urbanos também pode se converter em desvantagem pelo aumento nos custos de informação e transporte.

Por isso, junto à ênfase nos atributos específicos destes territórios, a literatura disponível chama igualmente atenção para a forma de inserção destas localidades no espaço extra-local (JACOBS, 1984; VELTZ, 2003), ou, como preferem alguns autores, para a relação das regiōes rurais com as cidades ou com outras partes do mundo. Nesta visão, é a economia da cidade que molda a economia das regiôes rurais. $\mathrm{E}$ isto acontece pela exportação de produtos primários, pela atração de atividades de transformação, ou pela captação da renda de setores urbanos, como aposentados ou profissionais liberais, estes em busca de segunda residência, ou via atividades turísticas. $\mathrm{O}$ fato é que, quanto mais estreitas forem estas relações, mais chance de prosperidade elas têm.

Como se pode perceber neste breve painel de definiçôes e orientaçôes, a rígida separação campo-cidade, que tanto influencia o senso comum, mas também o repertório de planejadores de políticas, se desloca para a complementaridade rural-urbano, ainda que preservando as contradiçóes típicas desta relação. Enquanto a primeira situação dizia respeito ao contraste entre espaços, sendo os campos o 
lugar de realização de atividades predominantemente primárias, destacadamente a agricultura; na segunda, o estatuto fundante da distinção desloca-se para o grau de artificialização dos ecossistemas e seus impactos para os modos de vida, exigindo assim uma abordagem capaz de combinar critérios ecológicos com outros de caráter social e econômico. É por isso, e não somente por uma questáo de concentração dos empregos, que o rural mostra-se não mais uma categoria passível de ser apreendida em termos setoriais, e sim territoriais. Algo cujo significado maior é a erosão do paradigma agrário que sustentou as visōes predominantes sobre o rural ao longo de todo o último século (FAVARETO, 2007) e a fragilização das bases do discurso da agriculture-led development strategy, ainda predominante no desenho das políticas de desenvolvimento rural.

Um diálogo entre estas definiçôes sugere que uma abordagem da história das relações entre campo e cidade deveria combinar a composição de critérios estruturais e funcionais com critérios relacionais, através de um tratamento da longa duraçâo da contradição (da unidade contraditória) entre os dois polos. É isso o que faz Georges Duby (1973) analisando a situação europeia e francesa em particular, até chegar a uma tipologia da interação destes espaços. Ou Fernand Braudel $(1979 / 1995 ; 1985)$ que em sua obra clássica confere às cidades - sempre tomadas em relação com os campos - o mesmo estatuto dado à moeda na evolução histórica da Civilização material e capitalismo: ambos são fundamentais para a ampliação das trocas. E, como diz Braudel, sans échange, pas de société. Não se trata, pois, de isolar ou eliminar um dos dois polos, mas de analisar a evolução de suas contradiçốes e interdependências, mesmo no auge da urbanização, como nos tempos atuais.

É por isso que atualmente, na Europa, são utilizadas definições diferentes em cada país, muitas vezes combinando vários critérios. (MATHIEU apud WANDERLEY, 2000) O mais comum deles é a demografia, e em dois sentidos: o tamanho da população e a densidade populacional. Outro bastante presente é a utilização do solo. $\mathrm{Na}$ Irlanda, por exemplo, as zonas com densidade populacional inferior a cem habitantes por quilômetro quadrado são consideradas rurais. $\mathrm{Na}$ Grécia, o teto que separa as áreas rurais das urbanas é dado pela densidade populacional de trinta habitantes por quilômetro quadrado. O mesmo vale para o limite de duzentas habitaçóes ou dez mil pessoas, na Dinamarca. Na Holanda e na Inglaterra, o principal definidor são as formas predominantes de utilização do solo. Na Alemanha é adotada uma tipologia que combina aspectos econômicos, demográficos e a utilização do solo. E na Itália, por sua vez, o limite de dez mil habitantes é acompanhado de uma lista de treze critérios funcionais

Muitas dessas definições são já bastante antigas e, em vários países, elas têm passado por tentativas de reclassificação, mais condizentes com as dinâmicas socioeconômicas e ambientais contemporâneas. 
Na França, em 1996 foi introduzida uma nova definição: o Zoneamento em Áreas Urbanas (ZAU). Com ela, os espaços urbanos passaram a ser categorizados em dois grupos: os "polos urbanos", onde há uma oferta de pelo menos cinco mil empregos; a "coroa periurbana", formada pelas comunas nas quais ao menos $40 \%$ da população ativa trabalha nos polos urbanos ou nas comunas sob sua influência. Juntas, estas duas categorias formam o espaço predominantemente urbano, o que no caso francês significava três quartos da população à época. De outro lado, também os espaços rurais tiveram sua delimitação mais refinada, sendo agora dividido em quatro categorias: o "rural sob fraca influência urbana", formada por comunas onde pelo menos $20 \%$ da população ativa trabalha num centro urbano próximo; os "polos rurais", pequenas localidades que oferecem entre dois e cinco mil empregos e que, portanto, comportam mais postos de trabalho do que habitantes, revelando-se um local de atração; a "periferia dos polos rurais", com as comunas nas quais pelo menos $20 \%$ da populaçáo trabalha nos polos; e finalmente, o "rural isolado", que no caso francês representa $10 \%$ da população total ou aproximadamente um terço do território. (INRA/INSEE, 1998)

Nos Estados Unidos, por sua vez, coexistem duas classificaçóes oficiais: a do U.S. Census Bureau e a do Office of Management and Budget (OMB). A classificação do U.S. Census Bureau lida com dados decenais e tem um caráter censitário. Nela as áreas urbanas são as mais adensadas, mas não correspondem a divisóes político-administrativas e podem ser de dois tipos: áreas urbanizadas ou "clusters urbanos". Numa área urbanizada deve haver mais de cinquenta mil pessoas, mesmo que não haja cidade com esse número de habitantes, e um núcleo com densidade superior a trezentos e oitenta e seis habitantes por quilômetro quadrado, podendo haver uma zona adjacente com um mínimo da metade dessa densidade. Por sua vez os "clusters urbanos" são localidades com população entre duas mil e quinhentas, e cinquenta mil pessoas, mas que atinjam os mesmos níveis de densidade demográfica. A população rural é definida com sendo aquela que está fora tanto das áreas urbanizadas quanto dos "clusters urbanos". Em 2000, 68\% da população americana vivia em quatrocentas e cinquenta e duas áreas urbanizadas, $11 \%$ em "clusters urbanos", e 21\% nas áreas rurais. (VEIGA, 2004a)

Já a classificação da OMB baseia-se em dados anuais de população, emprego e renda e tem um caráter político-administrativo. Nela são separados essencialmente condados metropolitanos (metro) e não metropolitanos (nonmetro). Um condado é considerado economicamente ligado a uma aglomeração metropolitana se $25 \%$ dos trabalhadores residentes estiverem ocupados nos condados centrais, ou se $25 \%$ de seus empregados fizerem o "movimento pendular inverso". Além disso, os condados "nonmetro" são subdivididos em duas categorias: as "micropolitan areas" (centradas em núcleos urbanos com mais de dez mil habitantes) e "noncore" para o restante dos condados. (VEIGA, 2004a) 
Outra classificação que merece destaque é aquela oferecida pela OCDE. Após análise de estatísticas referentes a cinquenta mil comunidades das duas mil microrregióes existentes nos países membros, a equipe de seu Serviço de Desenvolvimento Territorial passou a distinguir dois níveis analíticos. No nível local são classificadas como urbanas ou rurais as menores unidades administrativas, ou as menores unidades estatísticas. No nível microrregional as agregaçôes funcionais são classificadas como mais urbanas, mais rurais, ou intermediárias. Rurais são aquelas localidades cuja densidade populacional é inferior a cento e cinquenta habitantes por quilômetro quadrado, com a exceção do Japão, onde este número sobe para trezentos e cinquenta. Assim, as microrregiôes consideradas "predominantemente rurais" são aquelas em que a participação da população residente em localidades rurais excede 50\%; as microrregiōes "significativamente rurais", por sua vez, são aquelas em que a participação das localidades rurais fica entre 15 e $50 \%$; e as "predominantemente urbanas", por fim, aquelas onde as localidades rurais representam menos de $15 \%$ da populaçáo. Essa tipologia proposta pela OCDE é menos refinada do que outras existentes, mas tem a grande vantagem de cobrir um número expressivo de países e, com isso, oferecer possibilidades de comparação entre eles.

O primeiro ponto a destacar, derivado da apresentação desta forma de classificação, tem sido bastante sublinhado nos trabalhos que tratam do problema: o tamanho do rural mesmo no auge da urbanização. No conjunto dos países da OCDE, a população vivendo em comunidades rurais varia de um mínimo de $8 \%$, na Holanda, até um máximo de 59\%, na Noruega, e na maior parte dos países este percentual fica entre 20 e $45 \%$. Quando se trata de adotar a classificação por regióes rurais, observa-se que há uma grande heterogeneidade, mas nenhuma situação onde seja desprezível a proporção da população vivendo nas áreas predominantemente ou significativamente rurais ${ }^{2}$.

O segundo destaque não é tão evidente, e diz respeito ao significado destas formas de classificação. Fundamentalmente, o que há de comum nas novas tentativas empreendidas seja pela OCDE, pelo Insee, ou pela OMB, é a busca em ultrapassar as definiçóes substantivistas do rural, passíveis de serem expressas em um único critério ou dimensão, para formas onde seja possível vislumbrar seu conteúdo relacional ao urbano e às dinâmicas sociais e econômicas que lhe envolvem. Uma tarefa incontornável diante da mobilidade e da integração crescente entre os espaços. Algo que permite, para usar os termos do Insee (1998), falar dos "campos e suas cidades". E para isso, torna-se necessário utilizar combinaçôes de critérios estruturais e funcionais, e cobrir aspectos relativos às dimensôes econômica, social, ambiental e demográfica.

O principal significado destes movimentos nos quadros cognitivos de apreensão e classificaçáo é o crescente esvaziamento de sentido do rural como sinônimo de agrícola e de agrário. Em seu lugar, tem-se a emergência de uma visão 
territorial, o que implica no reconhecimento de uma lógica econômica cada vez mais intersetorial, e em uma escala geográfica de ocorrência de tais processos que remete à ideia de regiấo.

\section{As transformações do rural no Brasil contemporâneo}

\subsection{As dimensões do rural e do urbano no Brasil}

Trabalhos publicados nos últimos quinze anos (VEIGA et al., 2001; VEIGA, 2004b, entre outros) têm insistido que todo este debate sobre as tendências e ressignificaçóes do mundo rural contemporâneo é pouco absorvido no Brasil. E que, em grande parte, isso se deve à existência, entre nós, de uma regra única no mundo, segundo a qual é considerada urbana toda sede de município (cidade) e de distrito (vila), independentemente de suas características estruturais ou funcionais. E chega a citar como exemplo extremo o município gaúcho de Uniáo da Serra, uma "cidade" na qual o Censo Demográfico de 2000 só encontrou 18 habitantes. De um total de 5.507 sedes de município existentes em 2000, havia 1.176 com menos de 2 mil habitantes, 3.887 com menos de 10 mil, e 4.642 com menos de 20 mil. Todas elas com estatuto legal de cidade idêntico ao que é atribuído às regióes metropolitanas ou a destacados centros urbanos regionais. Surge desta clara distorçấo ou conveniência de critério o grau de urbanização do país, na casa dos $84 \%$ em 2010.

Muitos estudiosos sugeriram outra regra, procurando maior fidelidade ao que se poderia, de fato, chamar por urbano: não se deveriam considerar urbanos os habitantes de municípios com menos de 20 mil habitantes. Somente essa mudança de critério já faria com que se considerasse rural a população de 4.024 municípios brasileiros que tinham menos de 20 mil habitantes em 2000, o que alteraria o grau de urbanização para $70 \%$. O complicador aqui está no fato de que há vários municípios com menos de 20 mil habitantes e que apresentam altas densidades demográficas, invalidando assim um dos critérios que o tamanho diminuto da população tenta espelhar, que é o grau de interconhecimento entre a populaçáo local. Uma parte desses municípios estâo mesmo localizados em regióes metropolitanas e outras aglomeraçóes. Dois indicadores que caracterizam tipicamente o fenômeno urbano.

Para ser mais fiel à necessidade de combinar critérios estruturais e funcionais seria preciso envolver, no mínimo, o tamanho populacional do município, sua densidade demográfica e sua localização. Para isso, em Veiga (2004b) foi elaborada uma tipologia para a realidade brasileira fortemente inspirada na metodologia da OCDE, exposta na seçấo anterior. Aqui formou-se um primeiro grupo composto por microrregióes onde existiam regiôes metropolitanas ou ou- 
tras aglomeraçóes urbanas não-metropolitanas, ou ainda aquelas onde existisse ao menos um centro urbano com mais de 100 mil habitantes. Estas microrregióes foram consideradas essencialmente urbanas. Um segundo grupo, intermediário, chamado de predominantemente urbanas, concentrava as microrregióes que se encontravam em situação ambivalente. Aqui o critério decisivo foi a densidade demográfica, por ser considerada a mais próxima de expressar as modificaçôes do meio natural que resultam de atividades humanas: nada pode ser mais rural do que as áreas de natureza praticamente inalterada, e não existem ecossistemas mais alterados pela ação humana do que as manchas ocupadas por megalópoles. Para definir o critério de corte, foram realizados vários testes estatísticos, até que se considerasse sólida a proposição de definir como de pequeno porte os municípios que têm simultaneamente menos de 50 mil habitantes e menos de 80 hab. $/ \mathrm{km} 2$, e de médio porte os que têm população no intervalo de 50 a 100 mil habitantes, ou cuja densidade supere 80 hab./km2, mesmo que tenham menos de 50 mil habitantes. $\mathrm{O}$ terceiro grupo foi formado pelas microrregiôes cujos municípios apresentam tamanho diminuto de população e, junto disso, baixa densidade populacional. Este exercício foi atualizado por Favareto e Seifer (2011) utilizando os dados de 2010, cujos resultados são apresentados na tabela a seguir.

\section{Tabela 1}

Configuração territorial das microrregiōes brasileiras, 2010

\begin{tabular}{cccccc}
\hline Tipos de MRG & Número & $\begin{array}{c}\text { População 2000 } \\
\text { (milhões) }\end{array}$ & $\begin{array}{c}\text { População em 2010 } \\
\text { (milhões) }\end{array}$ & $\begin{array}{c}\text { Variação 2000-2010 } \\
\text { (\%) }\end{array}$ & $\begin{array}{c}\text { Peso relativo em } \\
\text { 2010 (\%) }\end{array}$ \\
\hline $\begin{array}{c}\text { Marcadas por aglomerações } \\
\text { Significativamente }\end{array}$ & 63 & 83,2 & 94,3 & 13,4 & 49,5 \\
$\begin{array}{c}\text { urbanizadas } \\
\text { Predominantemente ruais }\end{array}$ & 107 & 34,1 & 38,9 & 14 & 20,4 \\
\hline Total & 558 & 169,7 & 57,4 & 9,5 & 30,1 \\
\hline
\end{tabular}

Fonte: Favareto e Seifer (2012), elaborado com base nos dados dos Censos Demográficos (IBGE).

Como se pode observar 30\% da população seria, segundo esta tipologia, considerada rural. Algo próximo do dobro em relação às estatísticas oficiais. Mais, a redução nesse percentual no intervalo de uma década foi residual, de apenas 0,8\%. E trata-se de uma redução em termos de participação relativa, pois em termos absolutos houve um crescimento de 9,5\% da população vivendo em regióes rurais no período. Em termos gerais, a divisão populacional nestes três espaços manteve-se praticamente estável. São dados que apontam para duas constataçôes importantes: o peso do rural no Brasil contemporâneo não é nada desprezível, e nada leva a crer que sua importância relativa diminuirá no horizonte de médio prazo; logo, qualquer estratégia de desenvolvimento para o Brasil precisa, necessariamente, levar em conta a especificidade destes espaços. 
Os mesmos dados do Censo Demográfico revelam, ainda, outras tendências importantes quando são analisados, tanto a evolução do crescimento populacional por estratos de tamanho dos municípios, como a distribuição espacial deste crescimento populacional. Embora as diferenças sejam pequenas em termos de evoluçáo percentual, os tipos de municípios que mais ganharam participaçáo relativa na população total são as aglomeraçóes urbanas não-metropolitanas e os municípios com mais de cem mil habitantes.

Ao contrário do que se viu em décadas anteriores, e confirmando uma tendência já esboçada desde os anos 1990, as grandes metrópoles vêm perdendo a capacidade de atração populacional. Esse crescimento do que se poderia chamar de cidades médias, ainda que de maneira um pouco imprecisa, pode ser um trunfo para a interiorizaçáo do desenvolvimento. Isto porque, nos marcos da mudança de vantagens comparativas das regióes rurais, tal como indicado na seção anterior, é fato que nem todas as localidades rurais têm as mesmas condiçóes de experimentar um processo de desenvolvimento baseado em novas formas de uso social dos recursos naturais para além da produção de bens primários. A baixa densidade populacional, característica básica destes espaços, é um complicador para a diversificação econômica. O perfil demográfico e as características do tecido social, marcadamente das áreas rurais estagnadas ou daquelas que perdem população é outro: há uma fragilidade dos laços sociais externos, carência de oportunidades locais, baixa expectativa quanto às possibilidades de mobilidade social e de ampliação das interações. Distância de centros urbanos também pode se converter em desvantagem pelo aumento nos custos de informação e transporte.

Já uma outra tendência contrasta fortemente com este potencial aberto pela nova configuração demográfica do Brasil deste início de século, e pode ser claramente visualizada no mapa a seguir, onde se apresenta a evolução do crescimento populacional nas regiões rurais e sua distribuição espacial.

Aqui se vê claramente uma divisão nas tendências demográficas, com, de um lado, uma grande mancha que vai dos Pampas gaúchos ao Semiárido e aos Cerrados nordestinos, passando pelo Sudeste, na qual há uma perda de participação relativa destas regiōes rurais na população total do país. E, de outro lado, um adensamento populacional, ainda que suave, nas bordas e no interior da Amazônia. No caso do Centro-Oeste, o mapa indica uma dinâmica mais heterogênea na qual coexistem regiôes em adensamento, estáveis e em rarefação.

Talvez a grande novidade no Mapa 1 seja o fato de que a perda relativa de população rural não é mais uma realidade típica das regióes Norte e Nordeste. No caso do Nordeste esta tendência se mantém, mas isto é algo que agora atinge também a porção Sul do país em proporçôes muito significativas. 


\section{Mapa 1}

Crescimento populacional das microrregióes rurais

brasileiras, 2000-2010

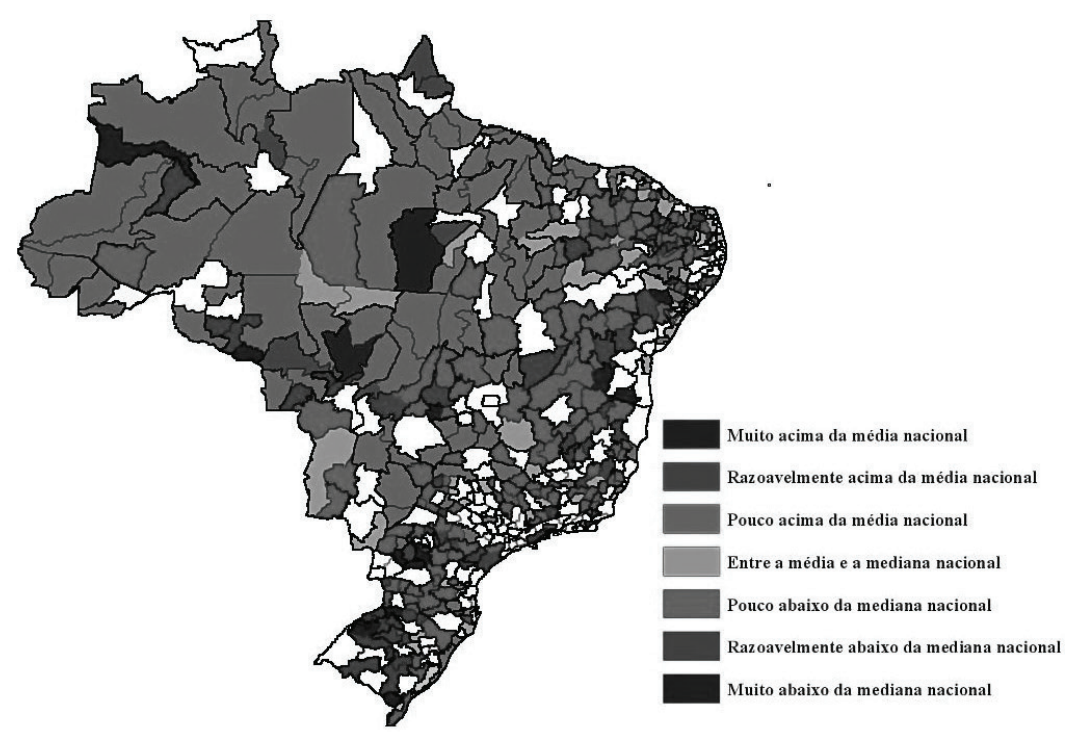

Fonte: Elaboração de Favareto e Seifer (2012), com base nos dados do Censo Demográfico (IBGE).

O que isso significa? Duas hipóteses podem ser cogitadas. A primeira é que as possibilidades abertas com a expansão das cidades médias não têm sido devidamente aproveitadas pelas regióes rurais. Diferente disso, elas têm se constituído como novos enclaves, repetindo o que já havia ocorrido desde os anos setenta com os chamados polos dinâmicos das economias regionais. Os mesmos dados sugerem ainda que, mesmo com o importante e significativo aumento da renda dos mais pobres, operado ao longo da última década por meio das transferências - com destaque para a Previdência Social, valorização do salário mínimo e Bolsa Família - pode não estar ocorrendo uma dinamização da estrutura produtiva e da vida social destas regióes interioranas, caso típico do interior do Nordeste, e que se traduza num dinamismo populacional. A outra hipótese é que as áreas interioranas de mais antiga modernização agrícola alavancaram durante algumas décadas seus indicadores econômicos e sociais, mesmo que, frequentemente, ao custo de forte desigualdade. Mas hoje este estilo de desenvolvimento parece náo ser o suficiente para vitalizar a estrutura social destas regióes a ponto de torná-las atrativas. Isso explicaria a perda relativa em áreas do Centro-Sul. Se esta hipótese estiver correta, não seria errado imaginar que o mesmo fenômeno se observará no Centro-Oeste, onde vem ocorrendo a expansão da moderna agricultura de grãos, em médio prazo. 


\subsection{As narrativas em disputa sobre o futuro do Brasil rural}

Se as dimensôes do mundo rural brasileiro não são nada desprezíveis, se não há mais tendências unívocas e que permitam predizer qual é o futuro dos espaços rurais, e se há novas tendências em curso, mas que se manifestam de maneira diferenciada, caberia perguntar entáo como o debate público vem considerando esta nova condição do rural e das relaçôes rural-urbano nesta virada de milênio.

Não seria errado dizer que há duas narrativas que polarizam as formas de compreender o papel e as possibilidades da agricultura familiar e os caminhos possíveis de desenvolvimento das regióes rurais. Não por acaso, nos últimos dois anos foram lançados dois livros reunindo artigos de pesquisadores brasileiros sobre o tema que podem ser considerados muito representativos destas duas visóes.

Um deles é o livro $O$ mundo rural no Brasil do século XXI (BUAINAIN et al., 2014). Este livro reúne dezenas de capítulos escritos por um número expressivo de pesquisadores, tendo como elemento motivador o polêmico artigo publicado pelos organizadores do livro um ano antes, com o título Sete teses sobre o mundo rural brasileiro. Há alguns poucos capítulos no livro que questionam as teses dos autores, e um grande número que as endossa e as desenvolve a partir de temas muito variados. Muito esquematicamente, o livro, e principalmente as sete teses que estão na sua origem, apresentam uma visão na qual desenvolvimento rural é sinônimo de desenvolvimento agrícola. Isto é, a única via de melhoria das condiçóes econômicas e sociais nas regiōes rurais seria promover a modernização e o desenvolvimento da agricultura, tendo, sobretudo, a tecnologia como variável chave e o aumento da produtividade como critério de êxito. O livro aponta uma tendência de concentração da produção, cujos ganhos crescentes de produtividade estariam tornando praticamente obsoletos boa parte dos estabelecimentos agropecuários brasileiros, destacadamente aqueles que não conseguem seguir o padrão de investimento e de atualização tecnológica necessários a continuar competindo. Vem daí o argumento de que muitos estabelecimentos familiares não seriam "viáveis" e, pois, não deveriam ser objeto de políticas agrícolas. Não é verdade que numa tal visão não há lugar para a agricultura familiar. É mais correto dizer que para os autores uma parte da agricultura familiar é viável: aquela que pode ser promovida ou tratada como agronegócio. O corolário destas teses é que o Brasil estaria passando por um processo de "argentinização": estaria em curso uma mudança rápida e estrutural da agricultura e dos espaços rurais brasileiros marcada pela concentração em grandes estabelecimentos, pela modernização da produção e pelo esvaziamento demográfico das áreas rurais decorrente da crescente tecnificação dos processos produtivos, gerando um panorama similar à paisagem típica dos campos do país vizinho. 
Um dos artigos do próprio livro (HELFAND et al., 2014) póe em xeque a ideia subjacente às sete teses de que haveria uma superioridade técnica viável somente nos grandes estabelecimentos. $\mathrm{O}$ autor mostra que há um segmento expressivo das grandes propriedades que tem produtividade muito baixa. E da mesma forma, é evidente que há um segmento da agricultura familiar que alcança patamares de produtividade e rendimento similares ao grupo dos melhores estabelecimentos patronais. $\mathrm{O}$ problema não estaria num segmento ou noutro, mas nos extremos: o segmento de melhor desempenho seria o segmento intermediário, que abrange tanto a agricultura familiar como a patronal. Logo, não há fatalismo quando a essas formas sociais de produção.

Outro dos artigos do livro (FAVARETO, 2014), questiona a associação que os autores das sete teses fazem entre desenvolvimento agrícola e desenvolvimento rural. Enquanto a primeira categoria é setorial e produtiva, a segunda é uma categoria espacial. Se durante muito tempo fez todo sentido compreender os espaços rurais, exclusivamente, a partir do que se passava no seu setor primário, desde o último quarto do século passado isso é impossível no Brasil. Basta lembrar os estudos conduzidos por José Graziano da Silva nos anos 1990, mostrando a importância das chamadas rendas não agrícolas para a estrutura das rendas das famílias rurais. Basta lembrar os estudos de Ricardo Abramovay e José Eli da Veiga, no mesmo período, chamando a atenção para o fato de que boa parte dos empregos e da atividade econômica das regiôes rurais não está mais na agricultura. Basta ver os estudos recentes de Nelson Delgado e Sergio Leite mostrando como, em boa parte da experiência internacional, hoje, há uma preocupação em criar marcos institucionais e formas de definição do rural que se definem justamente por sua intersetorialidade. E, finalmente, bastaria ainda mencionar os estudos de Maria Nazareth Wanderley que revelam a complexidade que cerca a relação entre os grupos familiares e suas formas de apropriação do espaço, que fazem do rural não somente um lugar de produção, mas também de moradia e de vida.

Esta visão está presente num segundo livro que representa uma espécie de extremo oposto às sete teses. Trata-se do livro Concepçóes da ruralidade contemporânea: as singularidades brasileiras. (MIRANDA; SILVA, 2013) Nele, o desenvolvimento rural envolve o desenvolvimento agrícola, mas é algo mais amplo, no qual as dimensóes social e ambiental têm conteúdo explicativo. A agricultura familiar (e a terra) têm mais funçóes a prestar para a sociedade do que ser o local da produção agrícola. Isso permite ver as regiōes rurais para além de seu papel de exportadoras de bens primários. As múltiplas formas de interdependência com o mundo urbano e a necessidade de expansão do bem-estar é que são os critérios de êxito. Nesta visão, a unidade de planejamento precisa ser expandida: é preciso pensar a unidade das relaçóes entre os campos e as cidades, a agricultura familiar e seu entorno. Nesta concepção as políticas agrícolas para os estabelecimentos familiares se justificam em praticamente todos os seus segmentos, pois a produção 
agrícola é parte das estratégias de reprodução social destas famílias. E sua manutenção é crucial para a constituição de um tecido social e econômico nas regiōes rurais, sem o qual é o próprio dinamismo da vida local quem perde vitalidade.

Os mapas a seguir mostram, aliás, que nas regiôes em que o desenvolvimento agrícola vai mais longe, a existência de empregos neste setor é menor. Dito de forma simples, há uma correspondência inversa entre desenvolvimento agrícola e inclusão das pessoas pelo trabalho agropecuário. O que torna evidente a necessidade de compor um feixe mais amplo de políticas para estas regiôes, sob pena de se constituírem regióes de produção dinâmica, porém altamente especializadas e esterilizando a vida social.

\section{Mapa 2}

Participação do PIB agropecuário no valor adicionado dos municípios, 2010

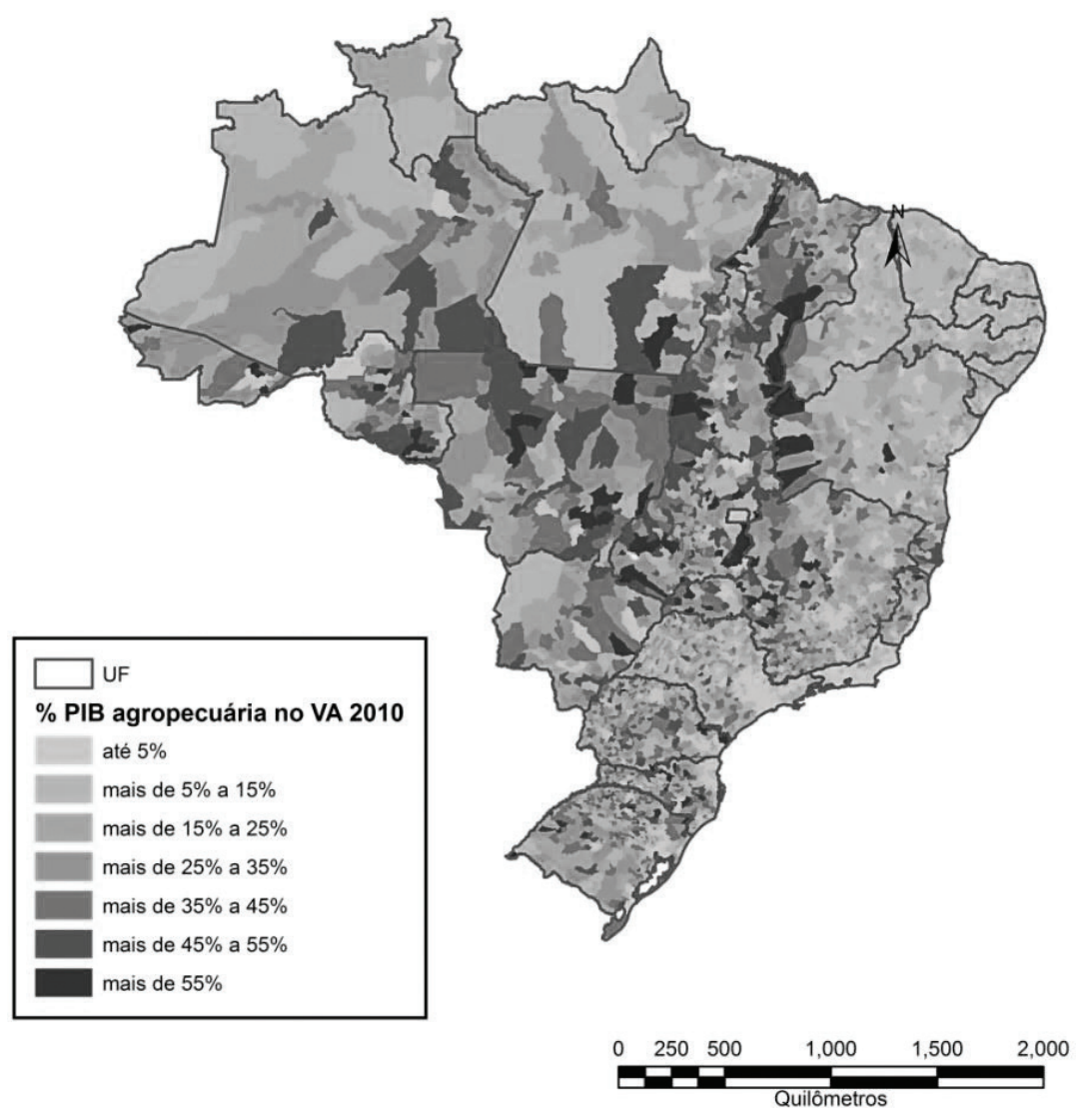

Fonte: Favareto et al (2014), com base nos dados do IBGE (2012). 


\section{Mapa 3}

Participação do emprego agropecuário e na pesca no

emprego total dos municípios, 2010

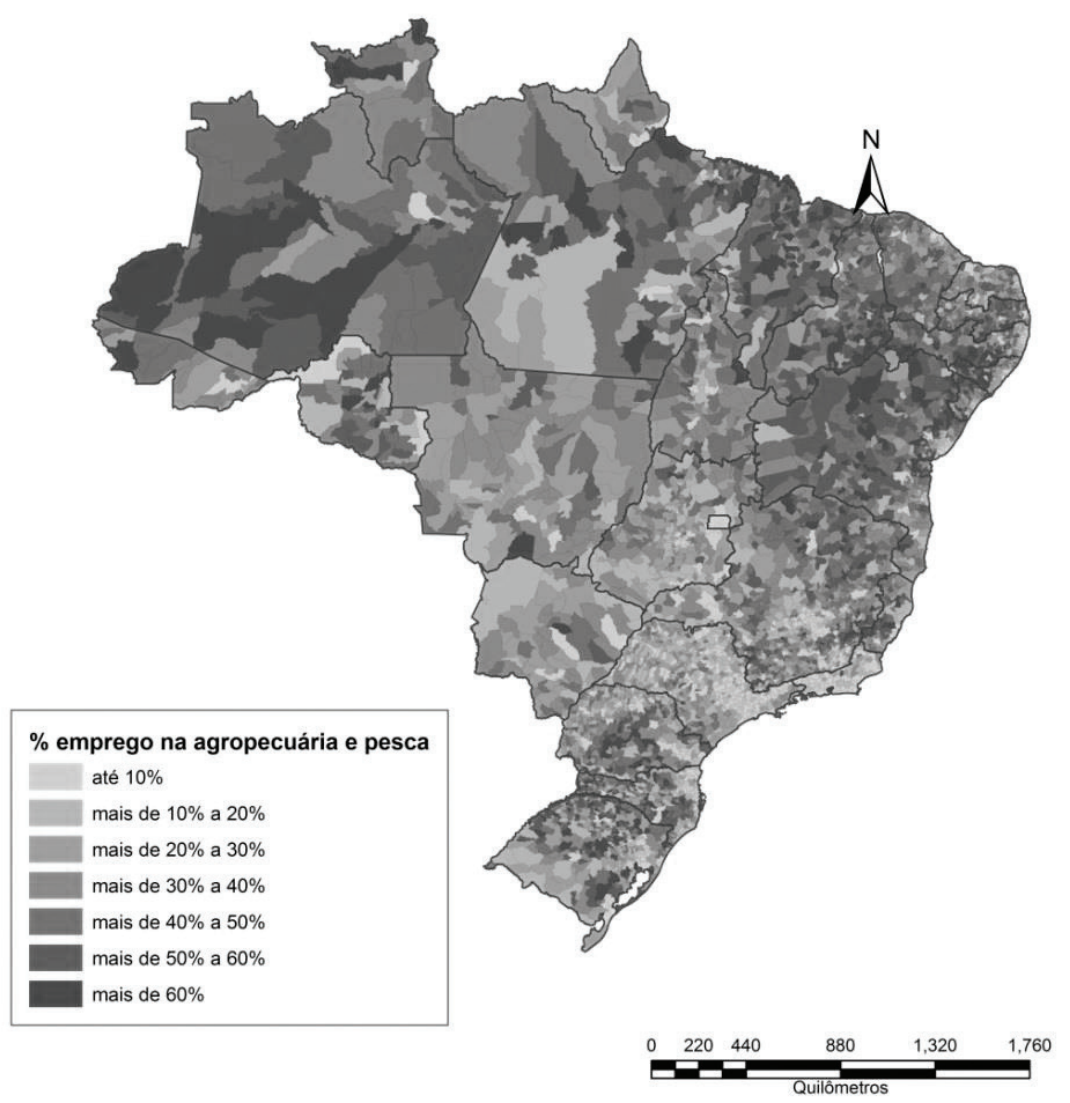

Fonte: Favareto et al (2014), com base nos dados do IBGE (2012).

Hoje as políticas que incidem sobre as regiôes rurais brasileiras representam um feixe de programas e açóes tremendamente importante. O estudo Territorial Review - Brazil (OCDE, 2013) reconhece isto e aponta que o desafio para a próxima década não está, provavelmente, na criação de novos instrumentos, mas principalmente na integração dos hoje existentes. Por um lado, como mostra a obra de Amartya Sen, a pobreza é sobretudo uma condição de privação de capacitaçóes a participar da vida social e poder escolher o que é melhor para si. Por outro lado, parte das oportunidades não pode ser criada pelos próprios indivíduos, eles dependem de um entorno favorável. Por exemplo, náo basta ser um trabalhador qualificado, é preciso que haja oferta de trabalho e um ambiente capaz de absorver este trabalho qualificado. Da mesma forma, os investimentos 
na agricultura familiar precisam ser completados com o estímulo à reestruturação produtiva das regiōes rurais na qual estes estabelecimentos estáo inseridos. Atualmente o grau de articulação é muito baixo, mas experiências recentes, como o Programa Brasil Sem Miséria, mostram que uma maior aproximação entre políticas e estruturas ministeriais é possível, desde que sejam objeto de prioridade e de uma clara estratégia, como no caso deste programa. A próxima seção arrisca algumas proposiçôes nesta direção.

\section{Que políticas, para que desenvolvimento rural?}

\subsection{As políticas de desenvolvimento rural}

Por onde passa então a gestação de conjunto de inovaçôes capaz de dar continuidade e de amplificar os resultados obtidos na década passada? Em Wanderley e Favareto (2014), há um esboço de ideias a respeito de referências voltadas a dar forma a um novo ciclo de desenvolvimento rural. Ali são apontados alguns princípios orientadores e eixos de intervenção. Quatro poderiam ser os princípios orientadores de um novo ciclo de políticas:

- Desenvolvimento náo é o mesmo que crescimento da economia (agrícola ou do país) - As políticas produtivas precisam se combinar com políticas sociais e de promoçáo do bem-estar, o que num certo sentido já vem acontecendo; o principal desafio futuro é justamente criar formas de mudar o estilo de desenvolvimento adotado, desconcentrando e diversificando a estrutura produtiva nas regióes rurais.

- É preciso reconhecer a especificidade do rural, não para separá-lo do urbano, mas para integrá-lo de maneira complementar - $\mathrm{O}$ planejamento das áreas rurais precisa se aproximar do planejamento urbano e do planejamento ambiental; hoje há estruturas distintas para o planejamento nestes três âmbitos que precisam ser integradas, favorecendo as convergências entre o rural e o urbano, entre os campos e as cidades, e estimulando novas formas de uso dos recursos naturais.

- Reconhecimento da diversidade do rural brasileiro e dos distintos caminhos de integraçáo destes espaços às dinâmicas de desenvolvimento do país - As múltiplas funçôes que os espaços rurais devem cumprir para a sociedade precisam compor uma estratégia única, para além do privilégio quase absoluto que ocorre hoje em relação à função de produção de matérias primas e alimentos. 
- Desigualdades espaciais como uma das formas mais perversas de restriçáo de oportunidades - Hoje um cidadão que nasce em certas regióes rurais está praticamente condenado a ter uma renda muito inferior àquele que nasce em áreas urbanas mais dinâmicas. Este mesmo cidadáo está condenado a ter menos anos de escolaridade ou a ficar mais exposto ao risco da morbidez precoce. É preciso compreender que a desigualdade de renda não é a única forma de desigualdade. Muitas vezes as desigualdades espaciais são tão ou mais importantes. E por isso precisam ser objeto de intervenção por meio de uma estratégia voltada à coesão territorial.

Estes princípios orientadores poderiam ser a referência para três eixos de intervenção, brevemente apresentados a seguir:

- Um pacto pela paridade entre o Brasil rural e o Brasil urbano - As organizaçóes sociais representativas das populaçóes rurais deveriam exigir do Estado o compromisso em fazer com que, no intervalo de uma geração, um habitante das áreas rurais tivesse acesso a um mesmo conjunto de serviços e equipamentos públicos que os moradores das áreas urbanas. Não pode existir no Brasil do século XXI cidadãos de primeira e segunda categoria, a depender do lugar em que vivem. É claro que certos indicadores e certos serviços sempre serão superiores no meio urbano, por uma questáo de escala, derivada da concentração populacional. Mas aspectos mais básicos e elementares precisam ser paritários nos dois espaços. Isso precisa ser feito por meio de um pacto, no qual Estado e sociedade se comprometem com a coesão territorial.

- Um novo marco institucional - $\mathrm{O}$ principal marco de regulação para o Brasil rural ainda é o Estatuto da Terra, que tem meio século de existência. De lá pra cá a realidade das áreas rurais e suas formas de inserção na economia e na sociedade brasileira mudaram significativamente. É preciso criar um novo marco, algo como um Estatuto do Brasil Rural coerente com as funçôes que estas áreas devem desempenhar no século XXI.

- Uma nova estratégia nacional de desenvolvimento para as regióes rurais - É preciso unificar numa estratégia coerente e coordenada o vigoroso mix de políticas e programas hoje existentes. Isto precisa ser feito numa direção que favoreça a reestruturaçáo produtiva das regióes rurais, de forma a endogeneizar o potencial de desenvolvimento que vem sendo impulsionado com a dinâmica recente do país. $\mathrm{O}$ Plano Nacional de Desenvolvimento Rural lançado há pouco tempo 
é um ponto de partida. Mas seu conteúdo ainda é excessivamente pulverizado e organizado em torno de princípios. Estes princípios precisam dar forma a uma verdadeira estratégia, com prioridades claras e sinalizando mudanças como a reforma das instituições e organizaçóes que atuam no desenvolvimento rural hoje existentes, a reforma de instrumentos hoje existentes como os Fundos Constitucionais, o fortalecimento de instrumentos ainda embrionários como o Zoneamento Ecológico e Econômico, ou a combinaçáo de iniciativas públicas e privadas, tanto no caso de mercados como de planos e projetos de desenvolvimento territorial.

\subsection{E as políticas educacionais?}

Num contexto como este, desde que haja concordância com a leitura sobre as tendências em curso, fica evidente que é necessário colocar as iniciativas e as políticas para a educação nas áreas rurais num outro patamar. E nisso, os desafios são de duas ordens.

Em primeiro lugar, é necessário expandir a oferta, sobretudo no ensino médio. O percentual de pessoas com 18 anos ou mais com ensino médio completo aumentou em média 56\% no Brasil entre 2000 e 2010; 85,86\% em microrregióes rurais e $51,16 \%$ em microrregiōes urbanas, e melhoras nesse indicador foram observadas em 99,91\% dos municípios brasileiros. Porém, em 2010, apenas 24\% dos municípios urbanos e $8 \%$ dos municípios rurais apresentavam percentuais acima de 33\% de sua população de 18 anos ou mais com ensino médio completo (os mais altos do país). A maior parte dos municípios brasileiros (62\% dos municípios urbanos e $74 \%$ dos municípios rurais) apresentava percentuais entre $16,1 \%$ e $33,5 \%$; e $12 \%$ dos municípios urbanos e $17 \%$ rurais apresentavam, ainda, percentuais abaixo de $16,1 \%$ da populaçáo com mais de 18 anos e nível médio completo. O Mapa 4 apresenta a distribuição espacial destes indicadores nos municípios brasileiros.

Já quanto ao ensino fundamental, as matrículas encontravam-se praticamente universalizadas no Brasil em 2010. Com aumento de quase $10 \%$ na última década, o país atingiu médias nacionais de $98 \%$ de matrículas de pessoas entre 7 e 14 anos nesse nível de ensino. $\mathrm{O}$ aumento na taxa de matrícula no ensino fundamental ocorreu em 89,83\% dos municípios do Brasil. A maior variação foi observada nas áreas rurais, com $12,51 \%$ de aumento das matrículas, enquanto a variação nas áreas urbanas foi de $8,66 \%$. Em geral esse indicador cresceu mais em áreas rurais do que urbanas, mas os municípios rurais ainda apresentavam os índices mais baixos de matrículas no ensino fundamental em 2010 (em média 97,62\%). Em 2010, 76\% dos municípios urbanos e 70\% dos rurais apresentavam 
entre $80,5 \%$ e $92,9 \%$ de matrículas no ensino fundamental, e apenas $15 \%$ dos municípios rurais e $12 \%$ dos urbanos apresentavam percentuais abaixo de $80 \%$.

\section{Mapa 4}

Percentual de pessoas com nível médio completo nos municípios brasileiros, 2010

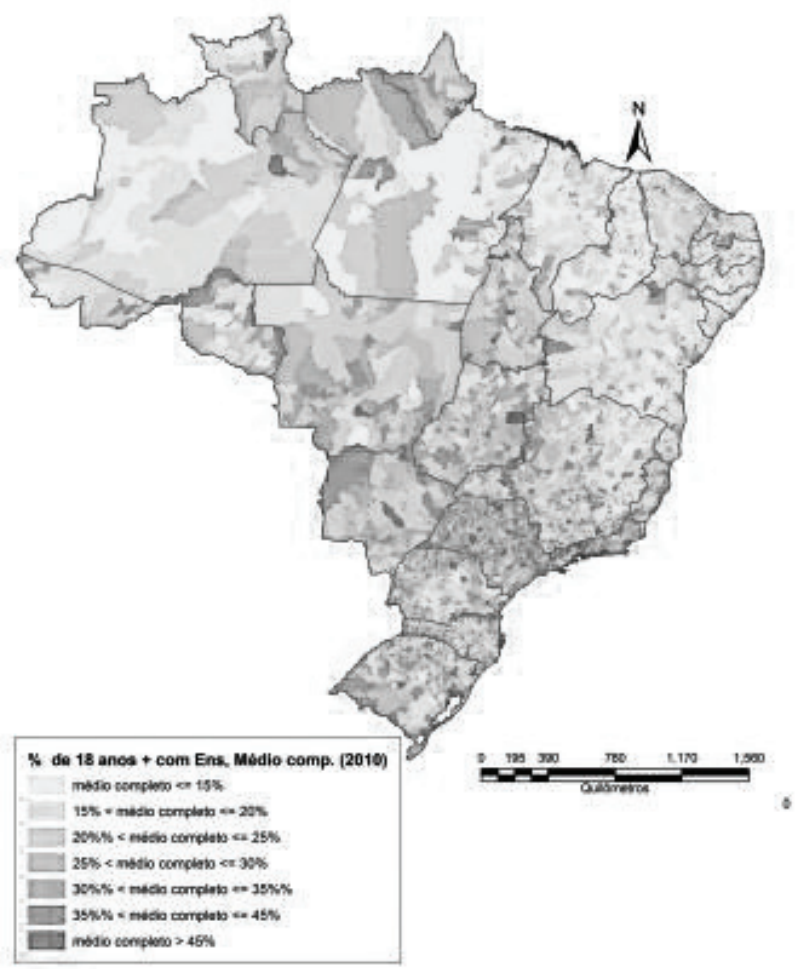

Fonte: Favareto et al. (2014) com base nos dados do Censo Demográfico (IBGE).

Isto, todavia, não significou a erradicação do analfabetismo. Em 2010, $90,28 \%$ da população brasileira se encontrava alfabetizada. Nas áreas rurais, esse percentual era um pouco inferior (83\%) do que nas áreas urbanas $(92 \%)$. O crescimento dos alfabetizados na última década foi de 4,64\% no Brasil, 7,57\% nas áreas rurais e 3,78\% nas áreas urbanas, e melhoras nesse indicador foram apresentadas por $98,78 \%$ dos municípios brasileiros. Porém, em 2010, 17\% dos municípios urbanos e $24 \%$ dos municípios rurais ainda apresentavam percentuais de analfabetismo acima de 26,1\%. 57\% dos municípios urbanos e $65 \%$ dos rurais encontravam-se na faixa média entre $6,6 \%$ e $26,1 \%$ de população analfabeta e $25 \%$ dos municípios urbanos e apenas $10 \%$ dos municípios rurais apresentavam 
percentuais abaixo de $6,6 \%$, o que denota uma permanência de diferenças importantes entre as áreas rurais e urbanas. (Mapas 5 e 6)

\section{Mapa 5}

Variação das taxas de analfabetismo nos municípios brasileiros, 2000

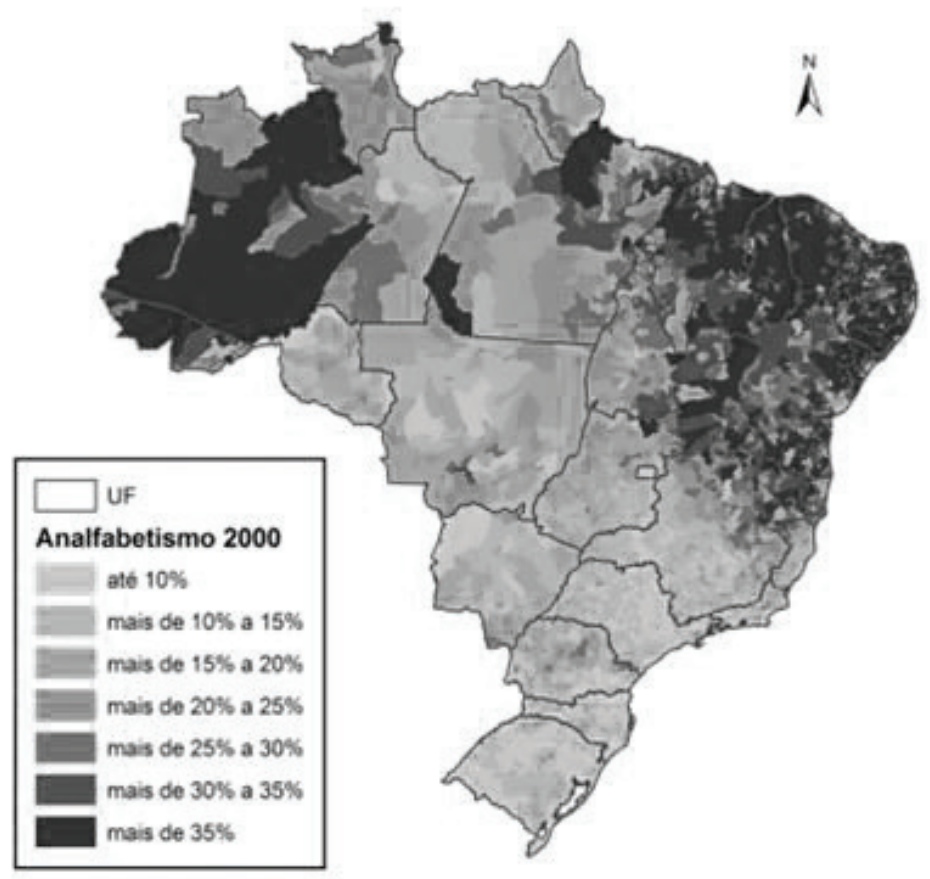

Fonte: Favareto et al. (2014) com base nos dados do Censo Demográfico (IBGE).

É sob este ponto de vista que a reivindicação por uma paridade entre as regióes rurais e urbanas se faz necessária. No Brasil do século XXI não é admissível que um cidadáo tenha $30 \%$ a menos de anos de estudo, somente por nascer em áreas de características rurais e náo urbanas, ou por ser um habitante do interior do Semiárido e não do Centro-Sul do país. O segundo desafio não é quantitativo, é qualitativo e tem a ver com o ambiente educacional ofertado aos jovens rurais. Se a educação é uma das capacitaçōes humanas fundamentais para poder participar da vida da sociedade, seu conteúdo precisa estar em consonância com as principais tendências contemporâneas, de forma a estimular e construir as habilidades necessárias aos indivíduos para que possam ler e interpretar criticamente a realidade em que estâo inseridos, mas também para estarem aptos a aproveitar as melhores 
oportunidades oferecidas por este novo contexto que vai se formando nas novas formas de relação entre os campos e as cidades nas regióes interioranas do Brasil. Para isso há alguns aspectos decisivos, exemplificados nos dois temas a seguir:

- A agricultura ou a produção primária do século XXI será significativamente diferente daquela praticada pelas geraçóes anteriores - Quando se fala em agricultura do futuro, para muitos vêm à mente a tradicional imagem das grandes plantaçóes, altamente mecanizadas, cultivadas com sementes transgênicas, monitoradas por satélite. Para outros a imagem é oposta: os requisitos ambientais e de saúde humana dos próximos anos trariam uma volta a padróes de produção mais rudimentares, com valorização da produção orgânica, livre de insumos químicos. Por certo durante algum tempo ambos os modelos continuarão a existir. $\mathrm{O}$ fundamental não é opor mecanicamente uma imagem a outra dentre aquelas aqui apresentadas. Mas justamente entender que os principais desafios residem em como ampliar a oferta de alimentos, porém, sob novas modalidades de uso dos recursos naturais. É preciso recusar o produtivismo a qualquer custo, típico da Revolução Verde, mas ao mesmo tempo sem desmerecer a importância da ciência e da tecnologia. Este novo padrão ainda é tateado pelas sociedades humanas e o Brasil teria todas as condições de liderar esta transição. Para isso, é preciso recusar as visóes do passado e valorizar as opçóes do futuro, reconciliando ciência e natureza.

- Nem todos os jovens rurais serão agricultores, e isso não é necessariamente ruim - É preciso aceitar com naturalidade a ideia de que nem todos os jovens rurais queiram ser agricultores. A atividade agrícola emprega cada vez menos trabalho à medida que se moderniza. $\mathrm{O}$ mais importante não é a atividade econômica a que estes jovens vão se dedicar. E sim o fato de que não precisem sair de suas regióes de origem para conseguir empregos e salários dignos. Fixar o homem no campo é uma ideia tão autoritária quanto estimular o êxodo e o abandono das regióes rurais, vendo apenas nas metrópoles o lugar de realização do futuro. Quanto mais diversificadas as economias destas regióes rurais, melhor para as famílias, pois se criam mais e melhores oportunidades de inserção econômica, sem desagregar o tecido social local. $\mathrm{O}$ crucial é que ser ou não agricultor seja uma opção destes jovens, um exercício das suas liberdades individuais, e não uma condenação por restriçóes (seja para uma ou outra opção).

- É preciso aproximar as escolas de ensino fundamental e médio das redes de ciência e tecnologia - Uma das principais novidades da última década foi o significativo processo de interiorização dos 
Institutos Federais de Educação, Ciência e Tecnologia e também das universidades públicas no Brasil. Entretanto, estas redes permanecem completamente desconectadas das redes públicas de ensino nos níveis fundamental e médio, salvo honrosas e pontuais exceçôes. Aproximar estas redes pode contribuir para um duplo intento. De um lado, favorecer um maior enraizamento destas instituições superiores nos contextos regionais locais, transformando-os em polos de geração de inovaçóes condizentes com os desafios que seguem pesando sobre as regióes rurais e interioranas do país, afastando-as do mero produtivismo. De outro, criar um ambiente mais estimulante para os jovens rurais, pondo-os em contato com profissionais destacados e com estruturas de ensino avançadas e gabaritadas para a produção de novos conhecimentos, projetando, por aí, um futuro diferente para suas realidades, em vez da mera repetição de trajetórias passadas.

\section{Mapa 6}

Variação das taxas de analfabetismo nos municípios brasileiros, 2010

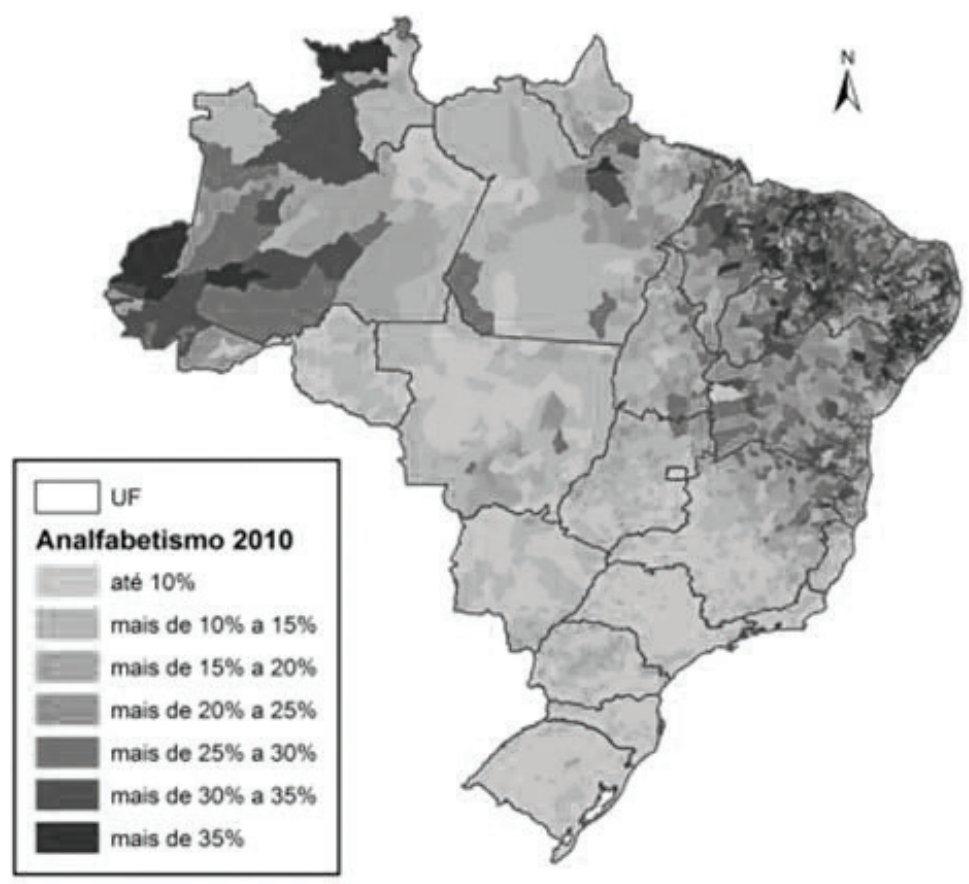

Fonte: Favareto et al. (2014) com base nos dados do Censo Demográfico (IBGE). 


\section{Conclusão}

As páginas anteriores trazem uma tentativa de mostrar como a humanidade vive um momento de transição de paradigmas e o caso brasileiro não é diferente. $\mathrm{O}$ paradigma agrário, que sustentou as principais teorias e políticas destinadas aos espaços rurais no século passado vem gradativamente dando lugar a uma nova visão, na qual a exportação de bens primários para as áreas urbanas passa a ser apenas uma, dentre as várias formas de relação possível entre os dois espaços. Este movimento precisa ser acompanhado pelas políticas públicas, em geral, e pelas políticas educacionais, em particular. As formas de resistência e crítica ao modelo produtivista que no Brasil tem na agricultora patronal seu portador principal podem dar lugar à afirmação de uma concepção de mundo rural capaz de reconciliar modernidade e solidariedade, ciência e natureza, produçáo e coesáo social. Os avanços sociais conquistados na década passada permitem pensar um novo patamar para políticas e programas, e há mudanças estruturais que podem favorecer a emergência de novas experiências e modelos. Esta nova condição deve ser objeto de reflexão por parte do Estado brasileiro e por parte da diversidade de forças sociais que vivem nas regiōes interioranas do país, materializando uma nova agenda para a próxima década e para as novas geraçóes de jovens rurais.

\section{Notas}

1. Parte desta seção é uma reediçáo atualizada de trechos publicados anteriormente em Favareto e Veiga (2006) e em Favareto e Seifer (2012).

2. Em Delgado et al (2014) há um apanhado bem mais completo e atualizado das diferentes formas de definição de tipologias de definição e classificação de áreas rurais e urbanas no panorama internacional e suas implicaçôes para as políticas públicas dos distintos países.

\section{Referências}

ABRAMOVAY, R. O futuro das regióes rurais. Porto Alegre: Ed. da UFRGS, 2003.

AMABLE, B.; PALOMBARINI, S. L'économie n'est pas une science morale. Paris: Raisons d'Agir, (2005).

BRAUDEL, F. La dynamique du capitalisme. Paris: Flammarion, 1985.

. Civilização material, economia e capitalismo. São Paulo: Martins Fontes, 1979/1995, 3v.

BUAINAIN, A. M. et al. Sete teses sobre o mundo rural brasileiro. Revista de Politica Agrícola, ano XXI, n. 2. Abril/jun., 2013 
BUAINAIN, A. M. et al. (Orgs.). O mundo rural no Brasil do século XXI - a formação de um novo padrão agrário e agrícola. Brasília/Campinas: Embrapa/Instituto de Economia da Unicamp, 2014.

DELGADO, N. et al. Tipologias de ruralidades em agências multilaterais e organismos internacionais selecionados. In: MIRANDA, C.; SILVA, E. (Orgs.). Concepçóes da ruralidade contemporânea - as singularidades brasileiras. Brasília: IICA, 2014. [Série Desenvolvimento Rural Sustentável n. 21].

. Concepçóes de ruralidade e políticas públicas na América Latina e na Europa: análise comparada. In: MIRANDA, C.; SILVA, E. (Orgs.). Concepçóes da ruralidade contemporânea - as singularidades brasileiras. Brasília: IICA, 2014. [Série Desenvolvimento Rural Sustentável n. 21]

DUBY, G. L'urbanisation dans l'histoire. Études Rurales, n. 49-50, janvier-juin. p. 10-14, 1973.

FAVARETO, A. Paradigmas do desenvolvimento rural em questão. São Paulo: Fapesp/ Edusp, 2007.

.Um contraponto à tese da "argentinização" do desenvolvimento rural brasileiro. In: BUAINAIN, A. et al. (Orgs.). O mundo rural no Brasil do século XXI - a formação de um novo padrão agrário e agrícola. Brasília/Campinas: Embrapa/Instituto de Economia da Unicamp, 2014.

. et al. A dimensão territorial do desenvolvimento brasileiro recente (2000- 2010). Serie Documentos de Trabajo - Rimisp. Santiago de Chile: Rimisp, 2014. Disponível em: <http://www.rimisp.org/wp-content/files_mf/14024192532014_FavaretoEtAlrelatorio_RIMISP_Mapas_Versao19Fevereiro.pdf>.

FAVARETO, A.; VEIGA, J. E. A nova qualidade das relaçôes rural-urbano - implicaçôes para o planejamento territorial do desenvolvimento. Relatório de Pesquisa. São Paulo/Brasília: Unicamp/CGEE, 2006.

HELFAND, S., PEREIRA, V.; SOARES, W. Pequenos e médios produtores na agricultura brasileira: situação atual e perspectivas. In: BUAINAIN, A. M. et al. (Orgs.). O mundo rural no Brasil do século XXI - a formação de um novo padrão agrário e agrícola. Brasílial Campinas: Embrapa/Instituto de Economia da Unicamp, 2014.

GALSTON, W. A.; BAEHLER, K. J. Rural development in the United States - connecting theory, practice and possibilities. Washington-DC/Covelo-Califórnia: Island Press, 1995.

INSEE/INRA. Les campagnes et leurs villes - contours et caractères. Paris, 1998.

JACOBS, J. Cities and the wealth of nations. London: Penguin Books, 1984.

MIRANDA, C.; SILVA, E. (Orgs.). Concepçôes da ruralidade contemporânea - as singularidades brasileiras. Brasília: IICA, 2014. [Série Desenvolvimento Rural Sustentável n. 21].

OCDE. Creating employment for rural development - new policy approaches. Paris; OCDE, 1995. 
OCDE. Territorial review - Brazil. Paris: OCDE, 2013. Disponível em http://www.oecd. org.

VEIGA, J. E. et al. O Brasil rural precisa de uma estratégia de desenvolvimento. Texto para Discussão n. 1. Brasília: Nead, 2001.

VEIGA, J. E. Destinos da ruralidade no processo de globalização. Estudos Avançados, n. 51, maio-agosto, 2004a, p. 51-67. . A dimensão rural do Brasil. Estudos Sociedade e Agricultura, n. 22. Abril, $2004 \mathrm{~b}$. . Nascimento de outra ruralidade. Revista Estudos Avançados, São Paulo, v. 20, n. 57, 2006.

VELTZ, P. Des lieux et des liens. Paris: Ed. de l'aube, 2003.

WANDERLEY, M. N. B. A emergência de uma nova ruralidade nas sociedades modernas avançadas; o "rural" como espaço singular e ator coletivo. Estudos sociedade e agricultura, n. 15, outubro, p.87-145, 2000.

WANDERLEY, M. N. B.; FAVARETO, A. A singularidade do rural brasileiro - implicaçóes para as tipologias territoriais e a elaboração de políticas públicas. In: MIRANDA, C.; SILVA, E. (Orgs.). Concepçóes da ruralidade contemporânea - as singularidades brasileiras. Brasília: IICA, 2014. [Série Desenvolvimento Rural Sustentável n. 21].

Recebido em 03 de janeiro de 2015.

Aprovado em 27 de fevereiro de 2015. 